\title{
What do Birds Sing? \\ On Animal Language in South Slavic Folklore
}

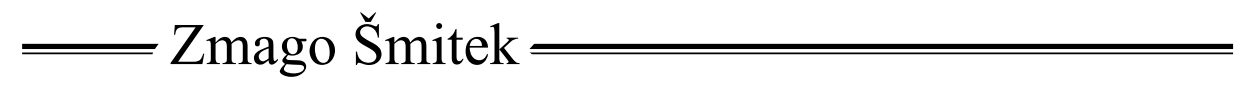

Contemporary scientific studies of ecosystems encompass different aspects of vocality, including the communication systems ("languages") of individual animal species. Current theoretical and experimental insights into "talking nature" call for a redefinition of such basic terms as "nature", "culture", "speech", "music", etc. In this context, it is therefore important to draw attention to intuitive and practical knowledge from within traditional and archaic cultures. The most interesting - and understudied - are the folk traditions about "animal language", "silent language" or "bird's language", which were supposedly known only to a few adepts, and could open the path to wisdom and success for them. We can find folklore motifs of this sacred or magical knowledge in folk-tales (ATU 670, 671 and 673 for instance) with their roots in animistic and shamanistic lifeworlds across different parts of the Eurasian continent. This paper will specifically focus on the south Slavic material, continuing the research first done and presented in a pioneering synthesis by the Macedonian ethnologist and professor Branislav Rusić.

KEYWORDS: animal language, bird's language, white snake, south Slavs, ecosystem, folktales

\section{MUDDLE OF LANGUAGES AND THE NEED TO UNDERSTAND}

In ancient and modern cultures across the globe, in Europe as well as elsewhere, birdsong has always been highly regarded for its melodiousness. Often it served as inspiration to writers and composers. In the $7^{\text {th }}$ century, the Toledo Archbishop Eugenius (Eugenius Toletanus) wrote a eulogy to nightingale singing, attributing to it perfection that surpasses human capabilities. Similarly, the bird kokila (Sanskrit for koel) taught melodiousness to the Indian poets. Moreover, birdsong could be explained in terms of a kind of language, which is why the Medieval Italian and Provance poets described birds as singing ciascuno in suo latino, which is to say each singing in its own Latin, meaning any language. Accordingly, Chaucer used the expression "falcon's Latin" (haukes ledene) in The Squire's Tale. ${ }^{1}$ Medieval Europe on the other hand saw in "bird's language" the secret language of the troubadours, the alchemists, and practitioners of the Jewish Kabbalah, that is to say - a magical language of the initiated few.

1 Susan Crane, For the Birds, The Biennial Chaucer Lecture, Studies in the Age of Chaucer 29 (2007),p. 25. 
In contrast to the poets of that time, the then theologians and philosophers were far more discerning and altogether stricter: they modelled themselves on the essays of Aristotle, Phytagoras and other theoreticians who saw in music a product of human rational creativity. Music in their case was always ennobled by a text, so it could not have been anything other than human. The robustness of this stance got its first more serious jolt towards the end of $13^{\text {th }}$ century, as instrumental music began to gain in prestige. In contrast to the precisely measured-out structure of choral music, it was not seen to be "real" music, and without the intellectual core it did indeed resemble bird singing. ${ }^{2}$ Already in the Middle Ages, instrumental and vocal music were characterized along the criteria rational/irrational, intellectual/intuitive. Today's science only affirms such a view, since it connects language (as text, speech or even as gestures) primarily with the sphere of the human left brain hemisphere, while acoustic signals (whistling, melodies) are seen to be linked primarily with the right brain hemisphere.

Human language is unique in that it names things. ${ }^{3}$ But, not unlike human beings, certain animal species too learn to form sounds according to certain rules that apply to the entire population, while at the same time having also a local or even individual expression. ${ }^{4}$ Bird song is characterized by short and simple sounds, either beckoning (as in the mating season) or warding off. The rhythm can be ever so fast, with the individual sequences lasting no more than a few seconds. Frequencies too are unique, as the human ear is unable to register the highest tones of bird song. As the Anglo-American ethologist Peter Marler has noted, on account of its complex permutations of vocal structures ("phonological syntax"), birds' calling compares more easily with human music than the sounds of any other animal species, even chimpanzees and monkeys as the closest relatives of human beings. ${ }^{5}$

It is in fact difficult to draw a sharp distinction between human language and bird song. Namely, every language has its own modulation, intonation, beat, rhythm and melody, which connects it with music. ${ }^{6}$ At the same time human communication does not depend entirely on language, but in certain cases includes also animal sounds. The line between human and animal "languages" is thus rendered only narrower. In an intuitive way, the similarity between human and animal languages was understood by people of ancient cultures, and this left traces in their collective memory and knowledge.

To a medieval European scholastic, neither the bird song nor composed vocal and instrumental music would have meant the pinnacle of perfection, since both were surpassed by the celestial music of the spheres (Musica mundana), the universal vibration

\footnotetext{
2 Elizabeth Eva Leach, Sung Birds: Music, Nature and Poetry in the Latter Middle Ages, Ithaca, N.Y.: Cornell University Press 2007.

3 Walter Benjamin, Selected Writings, Vol. 1 (1913-1926), Marcus Bullock and Michael W. Jennings (eds.), Cambridge (Mass.) - London: The Belknap Press of Harvard University Press 1997, pp. 62-74 (On Language as Such and on the Language of Man).

4 Keller, p. 169.

5 Peter Marler, Origins of music and speech: insights from animals, in: Nils L. Wallin et al. (Eds.), The Origin of Musics, Cambridge: MIT Press 2001, pp. 31-48.

6 Marcello Sorce Keller, Zoomusicology and Ethnomusicology: A Marriage to Celebrate in Heaven, Yearbook for Traditional Music 44 (2012), p. 173.
} 
connecting man to cosmos. The first to write about this were the Greek philosophers, but the work that brought the notion widespread popularity across Christian Europe was De institutione musica by the Roman philosopher Boetius of the $6^{\text {th }}$ century. The inaudible and highly subtle "music of the spheres" became the subject of various theoretical debates and speculations. This continued well into the subsequent centuries, while recently in astronomy observatories the sound notation of the low-frequency radio waves was recording, confirming that the universe is not silent and soundless and that each one of the planets of our solar system has its unique sound, as do also the stars, constellations and galaxies. It turned out that the idea about the "speaking and singing nature" was quite correct and all-encompassing.

Human interest in "what the birds sing" stemmed from their special status: as creatures of light and the skies they were mediators between everything earthly and spiritual. They symbolized divine ideals. Christian iconography recognized the Holy Spirit in the image of a white dove, Christ as phoenix or pelican, Mary as a turtledove, the evangelist John as an eagle and angels as winged creatures. Similarly, the ancient Egyptian Sky God, and the god of hunting and war Horus would manifest himself in one of his numerous shapes as a falcon or as a man with a falcon's head. The Nordic god Odin was accompanied by two ravens, while he himself could assume an eagle's body. The eagle is also an animal helper of the Siberian shamans and assists them in their ascent into the sky. On account of his great knowledge, he occasionally features as a shamans' adviser or even their father. ${ }^{7}$ Furthermore, the mythological Indian king of all birds, Garuda, bears the image of an eagle (Bhagavadgita 10.30).

Black birds would foretell death in the same way as night birds. Sometimes, they were seen to be a repository for unsaved spirits or souls of ancestors from the other world. Slavic demonology knows a big black bird with the name of movje or mavje (also navje, navi, navky, majky, etc.), which embodies the soul of a child who died before christening. Heaven is thus closed to such a soul, and so at night it associates with the likes of itself and can even lash out at people. However, if sprinkled with blessed water, it will turn into a white dove and soar into the skies. Man's soul does not leave the body only at death, but also in sleep, assuming the image of a bird, a fly, a butterfly or another flying animal.

From any number of cases it is possible to conclude that, alongside some other animals, the birds were keepers of secret knowledge unattainable to ordinary man. In the $10^{\text {th }}$ chapter of his book Germania (in circa 98), the Roman historian Tacitus noted that the inhabitants of his land foretell their future by observing the flight of birds and by listening to their sounds. This practice was widespread also in ancient Rome and Greece. Homer had put in the mouth of Hector that to him it makes no difference whether birds fly towards the sunrise or the sundown. Following the ancient Greek tradition, the Theban seer Tiresias, who had an entire flock of birds for this purpose, would also prophesy in the same manner. Because of his blindness, he had to rely on the descriptions of his helpers, while he himself could only follow the sounds of birds.

7 Clive Tolley, Shamanism in Norse Myth and Magic I., FF Communications, Vol. 296, Helsinki: Academia scientiarum Fennica 2009. 
Many versions existed regarding how Tiresias acquired the knowledge of bird's language. According to one, two snakes had cleansed his ears enabling him to have extraordinarily subtle hearing. Another had it that he had offended the goddess Hera, because he was supporting her rival Zeus. So, she punished him with blindness, while Zeus awarded him with the supernatural gift of seeing the future. According to a third version, he was blinded by the goddess Athena for having watched her while bathing. Heeding his mother's pleas, however, she later redeemed herself by gifting him with the power to understand bird's language and with clairvoyance. ${ }^{8}$ Freudian anthropologist Géza Roheim saw in the variations on Hera and Athena a misogynist tendency which can also be detected in the fairy tales of the type ATU 760 in the character of the cranky wife who pesters her husband to reveal the meaning of bird's chat to her. ${ }^{9}$

Medieval stories about Alexander the Great relate how he conversed with the birds in India to acquire their knowledge. Philostratus, for example, would attest to Indian wise men knowing also the secret of bird's language. According to Indian mythology, birds are the wisest of the animal species in the same way that Brahmins are the most educated of all the people. Both are "twice born": birds initially in the shape of an egg and then as animals, while Brahmins are born the second time when, following an initiation ritual, they receive a sacred thread.

Human and animal "languages" and "music" reveal themselves to be parts of the same sound space, or, put more accurately, the entire organic as well as inorganic ecological complex. A continuous stream of communication runs through all of nature. For the most part, voices of the animal ecosphere are seen to belong to the wild. The word connotates an unfriendly and uninhabited territory, a residing place of the demon, the devil, or idol. However, this is its secondary connotation, for etymologically it derives from the Indo-European stem * diuo as well as the ancient Slavic and old church Slavic divb, which means something shiny, heavenly or divine (as in Latin deus, Sanskrit deva and Avestan daeva). ${ }^{10}$ The change of this positive into a negative connotation may have occurred under the influence of the Iranian religious reform, when Zoroastrianism established itself and the expression daeva acquired a pejorative meaning (the god of old faith $>$ demon, evil spirit).

The term wild in some Slavic languages also means čarodejni/enchanting, while wild man denotes a forest man similar to a faun. Words such as divjost, divjaštvo and divjóta (all derivatives of "wildness" following Pleteršnik) carry meanings of brutality, primitiveness, inhospitableness, etc., and also have their Slavic parallels. ${ }^{11}$ Divjati (to go wild) means to charge forth with a great, unstoppable force (in the case of storms, floods, etc.). ${ }^{12}$

\footnotetext{
8 W.H. Roscher, Ausführliches Lexikon der griechischen und römischen Mythologie, Bd. 5, Hildesheim: Georg Olms Verlag 1965, pp. 182, 189 (entry: Teiresias).

9 Géza Roheim, The Language of Birds, in: The American Imago 10 (1953), No. 1, p. 8-9.

${ }^{10}$ Petar Skok, Etimologijski rječnik hrvatskoga ili srpskog jezika, prva knjiga, Zagreb: JAZU 1971, pp. 409-410 (entries: div, divan); Franciszek Sławski, Stownik prasłowiański, Tom III, Wrocław-Warszawa-Kraków-Gdańsk: Wydawnictwo polskiej akademii nauk 1979, p. 219 (entry: diviti).

11 Sławski, pp. 222-223, 227-228 (entries divostь, divota, divъ).

12 Sławski, p. 232 (entry divbjati)
} 
Parallel semantic expressions to diviti se, meaning to observe with interest and admiration, are also čuditi se (to marvel), občudovati (to admire), čudo (wonder), čudež (miracle), etc.

Following Blaise Pascal, we most admire what in fact we do not understand, while we can wonder at anything that is different or at least somewhat unlike what we are used to, be it in a positive or negative sense. The word čudo thus came to mean in some places in Istria "nobody and nothing"13. In Slovene Styria, čuden, strange, meant something repellent or even disgusting, while in Ukrainian and a dialect of Russian it only designated something funny (as in, for example, čudak, weirdo), and in Polish and in Kashubian something wonderful and charming! $!^{14}$ Even čudež, miracle, represents that which is contrary to the laws of nature.

With the Southern Slavs, the language of human communication with plants and animals was known as nemušti language, "animal language", alongside other similar designations. The Macedonian ethnologist Branislav Rusić has explained the meaning of nemušti jezik in the sense of a language of numb beings, with the term "nem", numb, potentially also meaning alien, incomprehensible ${ }^{15}$. The Serbian folklorist Ljubinko Radenković has collected a number of variants of this expression: nemučki language (Podrinje, Serbia), nemučni (Homolje), bezmitni (Herzegovina), nijemi (Karlovac), nemski (Macedonia) ${ }^{16}$. Primarily these various designations existed for verbal or musical communication with animate or inanimate nature and not only for communication through gestures.

According to the Austrian-Colombian anthropologist Reichel-Dolmatoff, simple Indian hunters have to this day remained so closely connected to nature that they have never been able to be either its rulers or admirers, for both instances require a certain distance. Amongst the archaic agricultural peoples, however, their concept of nature was ambivalent: nature was something that preceded culture and thereby was also subordinate to it, while at the same time it was also the dwelling place of deities, spirits and souls of ancestry, which elevated it above culture ${ }^{17}$. This also explains why the language of animals was nowhere undervalued as being of lesser worth than human language, but rather it was attributed supernatural qualities. Many Christian churches stand in places where shepherds had found their livestock gathered around the miracle-inducing icon of Mary. Other legends tell of various saints preaching to animals, giving them blessings and even christening them. The birds to which St. Francis preached not only understood the meaning of his words but they also responded to him.

\footnotetext{
13 Skok, pp. 339-340 (entry: čudo).

14 O.N. Trubačev, Etimologičeskij slovarb slavjanskih jazykov, vyp. 4, Moskva: Izdatel'stvo »Nauka« 1977, pp. 128-130 (entry: *čudo and *čudъnъ(jъ)).

15 Branislav Rusić, Nemušti jezik u predanju i usmenoj književnosti Južnih Slovena, Filozofski fakultet na Univerzitetot Skopje, Istorisko-filološki oddel, Posebni izdanija, knj. 5, U Skopju 1954, pp. 25-27.

${ }^{16}$ Ljubinko Radenkovič, Nemušti jezik, in: Slovenska mitologija: Enciklopedijski rečnik, Svetlana M. Tolstoj in Ljubinko Radenković (ed.), Beograd 2001, p. 380.

${ }^{17}$ Levi-Stros, Antropologija, p. 171.
} 
Following the principle of nature as subculture, the Greek-Roman and later also Judeo-Christian philosophy ordered domestic and wild animals into a system which was highly anthropocentric, separating out the animals on the basis of their practical use into working and unproductive, edible and inedible, clean and unclean, with the top of the ladder always reserved for horses, dogs and falcons, the animals assisting noblemen in hunting. ${ }^{18}$ Hunting in this form demonstrated the lord's power over nature, and implicitly also over society and culture. The multi-layered animal world at once ran in opposition to and in parallel with human society. It is in this context that the traditions of various peoples in which individual animal populations have their rulers can be made sense of.

The hierarchy of animal species can be juxtaposed to the differentiation in the value of different social classes. Ancient Greeks referred to foreign peoples as "barbarians" for their incomprehensible speech. Christened Romans used the same word for the bearded inhabitants of the plains who, in their view, lived like wild animals. Similarly, the Sanskrit term "barbaras" meant a foreigner and infidel. The Chinese too decked the surrounding peoples with various pejorative names that would classify them as animals. They would connect their northern neighbours most often with dogs or wolves, while those to the south with bedbugs or snakes. For some of these "barbarians" it was held that they lived in caves, dressed in animal and bird skins and communicate with animal and bird-like sounds. Narratives about the origins of some ethnic groups through the interbreed of human and animal ancestors belong to this same conceptual circle.

According to another Chinese classification, barbarians are either "cooked" or "raw", depending on the type of food they consume. The tribes within the Great Wall were considered to belong to the "cooked", while their relatives outside the barrier to the "raw". ${ }^{19}$ This implied that barbarians were not animal-like in the racial, but rather in a cultural sense and that accordingly they could be incorporated into the Chinese empire. However, until acculturation was achieved, foreigners had their designated place outside culture, in nature. Such thinking was in no way limited only to China, since as late as at the beginning of the previous century some German ethnologists and anthropologists still referred to the non-European tribes as "Naturvölker". ${ }^{20}$

Animals would also feature as metaphors for physical and temperamental strengths and weaknesses in humans. In his book Wild Thought, Claude Lévi-Strauss compared a population of birds with a human society, enumerating their mutual similarities ("language", nesting, etc.) as well as differences (flying in the air). ${ }^{21}$ Slovene peasants once imagined that in spring, in the wedding season, birds too got married.

Alongside animal languages there existed various human languages. Many of them were just as unattainable to the individual as were the animal languages. Take secret languages, for example, which, though derivative of local dialects, were deliberately

\footnotetext{
${ }^{18}$ Kristen M. Figg, Pets in the Middle Ages: Evidence from Encyclopedias and Dictionaries, Enarratio 18 (2013), p. 5.

${ }^{19}$ Magnus Fiskesjö, The Animal Other: China's Barbarians and Their Renaming in the Twentieth Century, Social Text 29 (2011), No. 4, pp. 57-79; especially 57,63, 65.

${ }^{20}$ Levi-Stros, Antropologija, p. 193.

${ }^{21}$ Klod Levi Stros Divlja misao, Biblioteka Sazveždja 12, Beograd: Nolit 1961, p. 241
} 
coded so as to be comprehensible only to the initiated. Most often they were intended for communication amongst members belonging to lower and marginal social groups. ${ }^{22}$ The language of vagabonds or offenders, as were Slovene rokovnjači is a case in point. In the Balkans, secret languages would include "goats" and "bovine" languages, which of course were not the languages of the animals but of their shepherds. In the urban environment, they degenerated to the level of child's play, while amongst the grown-ups, they found their place in jokes and slanderous remarks. ${ }^{23}$

Secret languages formed following different principles. Slovene latovščina and goats' and bovine languages are characterized by adding syllables to individual words. By rule, a word gets two syllable insertions, one of which must consist of one phonemene only, and that phoneme a vowel. By inserting the syllable $u$ and je, the word berem (meaning 'I read') would become urem beje. If there are three syllables, the addition of for example $k u, k$ and je turns the greeting dobro jutro (good morning) to kudokbroje kujuktroje. The third type emerges through syllable permutations in such a way that the word starts with the second and continues with the first syllable. The inversed order of syllables could also have been enacted by uttering whole texts in the inversed form, as for example, in the name Paul - Luap ${ }^{24}$.

Secret languages are especially interesting because they have similar characteristics of (in)comprehensibility to the magic language. Indeed, for every ceremonial language, if it is to attain its goal, it needs to be different from the spoken language. However, in contrast to secret languages, the magic language does carry a number of individual features: the phonetic effect, for example, takes precedence over meaning, that is to say the sound of words, their rhythm, repetition, loudness, and correct pronunciation with emphasis in the right places.

Comprehension of secret languages is made more difficult because of the specific nature of their syntax and semantics, whether this has to do with the insertion of nonsense syllables, connection and garbled words from different standard languages, or with changing the received meaning of the word. Deprecatingly, they could be described as muddled, if it were not for a certain muddle already built into the very foundations of each language. The Bible interprets this as having originated at the very beginning of human history, with the building of the city of Babylon and the tower. It was then that the Almighty said: "Behold, they are one people, and they all have the same language. And this is what they began to do". He then shuffled their languages and dispersed the sons of Sem all over the world (Gen 11:1-9).

God's imposition of discipline on humanity thus achieved its goal, for language implies being bound by a certain framework, which narrows our perceptions to what is describable. In the confusion of many languages coming in the wake of divine intervention, Jacques Derrida (drawing on Walter Benjamin) identifies a significant question "about the

\footnotetext{
${ }^{22}$ Corinna Leschber, Bulgarischen und makedonischen Geheimsprachen, in: Christian Efing, Corinna Leschber (Hrsg.), Geheimsprachen in Mittel- und Südosteuropa, Frankfurt am Main: Peter Lang 2009, p. 130.

${ }^{23}$ Sima Trojanović, Prilog tajnim jezicina, Južnoslovenski filolog 5 (1925-26), pp. 222-226; Milena Zovkova, O nemuštem i kozarskom jeziku, Glasnik Zemaljskog muzeja 2 (1890), pp. 236-237.

${ }^{24}$ See above note.
} 
urgent and impossible task of translation". ${ }^{25}$ Thereafter, "translation becomes law, duty and debt, but the debt, one can no longer discharge". ${ }^{26}$ This way every language, simply by virtue of its existence, begs, as it were, to be transmitted, translated and deciphered.

The linguistic barriers that plagued the common man were however easily overcome by Christ's Apostles. Following the Biblical tradition, they gave speeches about God's magnanimous deeds, which the listeners understood each in his own language (Acts 2, 5-11). Paul the Apostle termed this supernatural ability as "the gift of the Holy Spirit" (1 Cor 14.2). The gift of such a "universal language" did not in itself mean its comprehension. But he who had the first language could receive the second language, so the apostles themselves would understand the message that was previously given to them in an incomprehensible form.

According to the Bible, speaking "in tongues" was granted to all those who were possessed by the Holy Spirit. It was considered to be an angelic language, or the primeval, still undivided language of humanity. But it was unclear whether the incomprehensible speech in a state of ecstasy should also be seen as belonging to it. Such speech (glossolalia) was known to charismatic Christian sects of the last few centuries, and since the beginning of the $20^{\text {th }}$ century mainly to the Pentecostal Church, while it also crops up in medical cases of schizophrenia. ${ }^{27}$ Glossolalia, of course, is not a language in the true sense of the term, for it has no readily comprehensible meaning and no communicative function. As such, it is also different to the language of the Apostles which was comprehensible to their listeners.

Following some other explanations, glossolalia supposedly reveals "the deeper structures" of consciousness, which are manifest across cultures. ${ }^{28}$ These can also be linked with Noam Chomsky's theory of "universal grammar". With learned ritual technique, the practitioner of such speech would loosen his conscious control mechanisms, not unlike what happens in the state of drunken stupor. Interestingly, it was in the Biblical times that a similarity between drunken language and speaking "in tongues" was noted. By way of illustration, here is an excerpt: "Amazed and perplexed, they asked one another, 'What does this mean?' Some, however, made fun of them and said, 'They have had too much wine" (Acts 2. 12-13). That is why the jesting colloquial expression for strong liquor, in Slovenian, which is "snake's saliva"29, most probably does not refer to its strength but to the manner of slurred and confused speaking it brings on.

What is important to note here is that the idea of sacred "speaking in tongues" also finds reflection in popular beliefs. Following south Slavic interpretations, this type of communication was mastered not only by god and the devil, but also by the saints (e.g. Orthodox Saint Sava) as well as by fairies and witches. Slovene folktales mention wild

\footnotetext{
${ }^{25}$ Jacques Derrida, Izbrani spisi o religiji, Ljubljana: KUD Logos 2003, 164.

${ }^{26}$ Derrida, p. 168.

27 John McGraw, Tongues of Men and Angels: Assessing the Neural Correlates of Glossolalia, http://www. Academia.edu/147 4057/-Book-Chapter-Tongues-of-Men-and-Angels, p. 65.

${ }^{28}$ Felicitas Goodman, Speaking in tongues: a cross-cultural study of glossolalia, Chicago: University of Chicago Press 1972.

${ }^{29}$ Slovar slovenskega knjižnega jezika (further SSKJ), SAZU 2001, pp. 727 and 1442 (entries kača and slina).
} 
women speaking in a peculiar language incomprehensible to anyone, which may have also been a language of animals and plants, though there is no explicit mention of that. ${ }^{30}$

There were many explanations as to the conditions and procedures enabling a person to understand the voices of nature, which could be classified as mythological, theological, and magical. To a mythological hero, this faculty was innate, or he could acquire it from a supernatural being (god, fairy, snake king) as payment for a given service. Prince Marko, for example, without any preparations, could understand the speech of his horse, while the hero of Norse mythology Sigurd could only begin to understand bird speech after consuming the blood of the conquered dragon. The mythological heroes could even morph into different animals and plants on the strength of their own will, as could fairy-tale characters (as for example, in type ATU 325) ${ }^{31}$. Of course, in all cases these metamorphoses were only temporary.

With the help of conjuring and incantation it was ultimately possible to bring about forced transformations of people into animal beings. Let us enumerate a few instances to demonstrate the widespread and enduring nature of such beliefs: the Sumerian goddess Ishtar could change her lovers into lions, wolves, horses and birds in this way; Homer's witch Circa would transform her rivals into lions, wolves, swine, and donkeys. Slovenian ballads evoke the sadness of a mother who, in a bout of anger, changed her wayward daughter into a fish or rebellious son into a $\mathrm{crow}^{32}$. In pre-Christian Europe, though the boundaries between humans and animals were easily crossable, an enforced transformation of a human being into a (subordinate) animal was always considered punishment.

In the mythological context, the problem of deciphering animal language was left to the hero himself, his physical powers, and intuition. This straightforward situation, however, became complicated once religion intervened. The Bible, for example, demonstrates, very concretely, the general rule whereby religion tries to subjugate mythology, as it attributes man's cessation of unlimited communication with nature to the will of God, a will that is impossible to withstand. I have dealt with Slovene folk tales related to this subject in detail elsewhere, so here I will only mention the Montenegrin folk variation whereby God, after the Great Flood designated a separate language for the people exclusively intended for communication amongst themselves. ${ }^{33}$ Even more telling is a variation from Bosnia (in my translation):

In ancient times, it was not only man who could speak, but also animals and even trees. This was much better for man, because animals, trees, herbs, and stones could tell him why they were good for him and why they were intended for him from God. In those days, man was truly

\footnotetext{
${ }^{30}$ Roberto Dapit, Monika Kropej, Visoko v gorah, globoko v vodah: Velikani, vile in povodni možje, Zakladnica slovenskih pripovedi, facs. 1, Radovljica: Didakta 1999, p. 27 (no. 16).

31 A Slovenian example would be Josef Kosi's record from the area around Ljutomer, Archive ISN, ŠZ 7/38,2. In: Monika Kropej, Pravljica in stvarnost. Odsev stvarnosti v slovenskih ljudskih pravljicah in povedkah iz Štrekljeve zapuščine, Zbirka ZRC 5, Ljubljana: Znanstvenoraziskovalni center SAZU 1995, pp. 117, $236-237$.

${ }^{32}$ Karol Štrekelj, Slovenske narodne pesmi, facs. 1, In Ljubljana 1908-1923, no. 631 and 289.

${ }_{33}$ Zovkova, p. 236.
} 
happy! But the happiness was short-lived, because after having sinned, everything changed and everything became numb and silent. This is how man was punished from God and forgot all the different good uses he had learnt earlier from the animals and other speaking things. They still speak even today, but man cannot hear them. Only he who is good can hear them, but only once a year, at Christmas time, because then God grants such souls mercy to learn what would happen throughout the year, what they should protect themselves against and how to attain happiness and avoid unhappiness. ${ }^{34}$

In the narration above, we can recognize elements of the myth of "the golden age" of humanity known to many cultures. Ancient Greek tradition placed it into the mountainous landscape of Arcadia, land of simple peasants ruled over by the god Pan. The Greek poet Babrios, for example, writing in the late $1^{\text {st }}$ and early $2^{\text {nd }}$ centuries, would, in the prologue to his book of fables, reminisce about ancient times, when the earth bore fruits without human effort and people lived in the company of gods. Then all animals, together with man, spoke the same language, comprehensible also to a stone or a pine tree. The sea spoke to the ship and sailors and birds knew how to converse with fellow beings. ${ }^{35}$ However, after Pan's death, the "pagan" golden age went into gradual decline. In a different context, the Biblical episode of Adam and Eve's carefree life in Eden ended similarly tragically (with the first sin and God's punishment).

Following one Slovene apocryphal legend, man's conflict with God, which started with the original sin and continued with the building of the tower and the mixing of languages, only intensified. According to this legend, there was a time when crows were the favourite amongst all the birds. Hearing their voices, people would forget their everyday chores and abandon prayer. God was so upset with them that he turned their captivating singing into unpleasant crawing ${ }^{36}$. God in this case was bothered merely by the melody of bird's "speech", as it meant a type of competition. It must have been shocking to find out that the Christian (and generally monotheistic) God is above all an observer who, in line with his observations, also actively intervenes. This is what differentiates him from the gods of the earlier era. Nothing escapes him, and to make matters worse, he cannot forget anything, he can only forgive. Neither angels nor people can control him. Even an attempt to do so constitutes revolt and $\sin .^{37}$

Although the Christian faultline between human and natural micro- and macrocosmos was strongly and irrevocably demarcated, with all the linguistic and other consequences, it somehow became possible, once a year, around Christmas time, for a few moments, to

\footnotetext{
${ }^{34}$ Zovkova, p. 236.

${ }^{35}$ Eugene Lévèque, Les fables Ésopiques de Babrios, Paris: Belin frères 1890, p. 27.

${ }^{36}$ Vesna Penec and Lidija Toplišek, Petrina in Striček, Folklorne pripovedi iz okolice Celja in Laškega, Zbirka Glasovi, facs. 36, Celje 2009, p. 116-117 (no. 115). See also: Monika Kropej Telban, Tipni indeks..., pp. 384-385.

${ }^{37}$ Niklas Luhmann, Das Medium der Religion. Eine soziologische Betrachtung über Gott und die Seelen, Das Medium der Religion....p. 45.
} 
understand the conversations of domestic livestock, but only for those who had no sins and were privy to God's special benevolence. ${ }^{38}$ Such individuals could even be granted a long-term and not just temporary knowledge of this sort. This is beautifully demonstrated in the introduction to a fairy-tale from Struga in Macedonia (ATU 671):

There lived an impoverished young man, alone. He prayed to God, he did no wrong, such was his soul. He said: "I want nothing, I want nothing, but if I could speak the language of cows, swine, birds. If I could speak all languages, all of them". The Lord heard him out. Because the young man was doing good, God taught him all the languages. ${ }^{39}$

According to the south Slavic folk tales, the circle of those who could communicate with the world of nature encompassed as yet unlettered children alongside those adults who lived in, and with, nature: shepherds, woodcutters, hunters, etc. It was particularly the professional, hired shepherds, travelling from village to village (more on them later), who were endowed with "special, magic, supernatural gifts as a result of being connected with the other world". ${ }^{40}$ The list could be enlarged to include those who have proven themselves with their entrepreneurship and valiance. ${ }^{41}$ To everyone else, however, this privilege was unattainable, generating a feeling of being neglected. All the more so, since it was through the knowledge of animal speech that opportunities for becoming rich fast would arise easily.

There was consequently no dearth of candidates who tried to enter the world of the initiated through the side door, with the help of magical means: consuming a soup of snake's flesh, coming into the possession of a fern blossom or seeds, etc. This mentality is visible in the folk tales from the Kamnik region, namely in the belief that anyone consuming a snake's heart could acquire the faculty of transforming into another creature. ${ }^{42}$ The ritual (as a strategic means of behaviour to attain a goal) in this case sidestepped social control, assuming instead the role of a safety valve which could regulate social and personal tensions.

In many places, the serpent and the bird are the basic and the most frequent magic prerequisites. In Serbian folklore, a stick with which a man touched a snake that had caught a bird is seen to carry magical powers. In various magical procedures, the bird is often replaced by a hen or its feather. ${ }^{43}$ The hen, chicken or an egg are also indispensable to Slovene witchcraft. The opposition between bird and serpent thus emerges, for

\footnotetext{
38 Rusić, p. 57.

${ }^{39}$ Kleanti Liaku-Anovska, Vlaškite narodni prikazni od Struško, Skopje: Institut za folklor Marko Cepenkov 2004, p. 245 (Posebni izdanija. 54).

${ }^{40}$ Mirjam Mencej, Pastirji - čarovniki, Studia mythologica Slavica 3 (2000), p. 115.

${ }^{41}$ Rusić, pp. 37-38, 43-44.

${ }^{42}$ Vinko Möderndorfer, Verovanja, uvere in običaji Slovencev, Knj. 5, Zadružna knjižna izdaja 19, Celje: Družba sv. Mohorja 1946, p. 238, no. 1801-1802.

${ }_{43}$ Ljubinko Radenković, Narodna bajanja kod južnih Slovena, Beograd: Prosveta-Balkanološki institut SANU 1996, p. 23.
} 
example, in the deed of scattering shells of blessed Easter eggs so as to block snakes from entering peasant houses. ${ }^{44}$

Natural magic should not be seen as entirely devoid of rationality, and could be designated as a branch of medieval science, which in contrast to modern theories primarily built on associations. However, the line between the two was blurred in the mind of the layman, as seen from the $17^{\text {th }}$ and $18^{\text {th }}$-century traditions discussing travelling students of "the black school" (i.e. theology) and clerics who were endowed with capabilities of sorcery. ${ }^{45}$ They were also dubbed as students of the thirteenth or Babylonian school. Not entirely without reason, since such individuals, literate and also with some knowledge of Latin, were indeed important mediators of magical knowledge to the peasant folk.

Folk memory has retained a story about a student from the valley of Trenta who, while studying, gave himself over to the devil in exchange for paid fees. Later, he sought advice from Saint Šembilja (Sybil), who told him how to save himself and even gifted him the powers of prophesying. ${ }^{46}$ It is thus not surprising to find amongst the fairy-tale variants belonging to the type ATU 671 a son learning languages of birds, dogs, and frogs in school. Initially, this would have been "a forest school", as is seen from one Latvian story. ${ }^{47}$ According to one Slovene fairy-tale, a farmer's son learnt in a town school how to understand the croaking of frogs, the barking of dogs, and the chirping of birds (which symbolically means the language of water, land, and air creatures), and with this knowledge he then acquired riches and respect. ${ }^{48}$

\section{THE CODE OF THE SERPENT}

The most interesting and the most widespread amongst the fairy-tale types that touch on the subject of animal languages is the one with the designation ATU 670, "Man who understands the languages of animals". While it can be found across different cultures in Europe, Asia and Africa, its thematic framework is relatively uniform: a man acquires the power of understanding animal language from a serpent who owes him a return favour, but with the warning that he will die if he reveals this knowledge to anyone else. One day, he overhears a conversation between animals and he laughs out loud. His inquisitive wife wants to know the cause of his laughter. Already exhausted from her pestering, he is ready to give in, but in that moment, he hears a cockerel boasting how easily he lords over his hens. Then the man shuts his mouth and does not give away his secret. ${ }^{49}$ The

\footnotetext{
44 Aleksander Videčnik, Rože in čarovnije, Mozirje 1995, p. 102.

${ }^{4}$ Vatroslav Jagić, Južnoslovenske narodne priče o grabancijašu dijaku i njihovo objašnjenje, in: Vatroslav Jagić, Izabrani kraći spisi, Zagreb: Matica Hrvatska 1948, pp. 190-191.

${ }^{46}$ Simon Rutar, Slovenski Faust, Ljubljanski Zvon 1882, p. 536.

${ }^{47}$ Antti Aarne, The Types of the Folktale, FF Communications, No. 184, Helsinki: Academia scientiarum Fennica 1961, p. 235.

${ }^{48}$ Kaj ptiči pojo?, Arhiv ISN ZRC SAZU, ŠZ 7/217, 26. In: Monika Kropej, Pravljica in stvarnost, Ljubljana 1995 , p. 219 (no. 51).

${ }^{49}$ Hans-Jörg Uther, The Types of International Folktales. A Classification and Bibliography, Part 1, FF Communications, No. 284,Helsinki: Academia scientiarum Fennica 2004, p. 365.
} 
entire narrative can be divided into three thematic components: hero's learning of the animal language, the conflict with his wife, and the resolution of the conflict.

Over a century and a half ago these kinds of fairy tales attracted the interest of European scholars, who studied them mainly from the perspective of migration theory. ${ }^{50}$ It turned out that they supposedly originated in India, since some of them were included in the Jataka collection of tales, the stories about Buddha's previous incarnations, around the 4th century $\mathrm{BC}^{51}$. They also crop up in the epic of the Ramayana, in Harivamśapurāna, in Jain literature, in the medieveal Tamil collection of educational stories the Vetalapanchavimshatika and in a similar collection Sukasaptati, Munipraticaritam, and others. In various translations, they became known across Asia and also spread to Europe. ${ }^{52}$ Respectfully old is the Greek version, which tells of the mythical seer Melampus, known in the Homerian times, receiving the gift of understanding animal language from two baby serpents that he had saved from death and nurtured. Other European variants go back to the period after the year 1110 (e.g. Gesta Romanorum 1300).

Today the fairy motif ATU 670 is known practically all over the world, in Europe and especially in its eastern and south-eastern corners. With respect to the Southern Slavs, the variants deserving particular mention are those in Croatian and Serbian, as well as Macedonian and Bulgarian, and they completely coincide with Aarne Thompson's model. ${ }^{53}$ The transcription surviving amongst the Slovenes is of the story called Castle's Shepherd collected by Ivan Šašelj. In this notation, a shepherd saves a serpent from the fire and in doing so earns a prize for himself. The serpent king offers him the payment in gold and silver, but the shepherd refuses, saying: "If you want to give me something, give me nemštim, I won't take anything else". The snake sneezes into his face three times and thereby gifts him the secret knowledge..$^{54}$ In the usage of the term čoban and even more so in in the word nemštim, which is probably a derivative of nemušti language one can see the influence of settled Serbian immigrants (uskoki).

The above example also reveals that the knowledge of animal language can be transferred to a person with the serpent's saliva. A serpent "sneezing into [someone's] face" is often found in a variant form of someone spitting into a person's mouth. The motif of spitting into the mouth is known from the tale of Glaucus, son of king Minos. According to this tale, the prince, a one-time pupil of the Wiseman Polieidos, lost (or

\footnotetext{
${ }^{50}$ More about that: Kaarle Krohn, Übersicht über einige Resultate der Märchenforschung, FFC Communications, FFC. 96, Helsinki: Academia scientiarum Fennica 1931, pp. 53-57.

${ }^{51}$ Friedrich von der Leyen, Die Welt der Märchen, Bd. 1, Düsseldorf: Eugen Diederichs Verlag 1953, pp. 192-193.

${ }^{52}$ Antti Aarne, Der tiersprachenkundige Mann und seine neugierige Frau. Eine vergleichende Märchenstudie, FF Communications, No. 15, Hamina: Suomalaisen tiedeakate kustantama 1914, p. 24.

${ }^{53}$ See for example Matija Valjavec, Narodne pripovedke. Človek znal živinski govor, Kres 5 (1885), pp. 27-29; Snežana Marković, Pripovetke i predanja iz Levča, Novi zapisi, Beograd-Kragujevac: SANU in Univerzitet u Kragujevcu, Čigoja štampa 2004, pp. 30-31 (no. 19, 20); Marko K. Cepenkov, Makedonski narodni umotvorbi, Knj.I., Narodni pesni, Skopje: Makedonska kniga, Institut za folklor 1980,no. 84, 85; Liliana Daskalova Perkowski et al., Typenverzeichnis der bulgarischen Volksmärchen, Helsinki: Academia scientiarum Fennica 1995, p. 136 (FFC 257).

${ }^{54}$ Ivan Šašelj, Bisernice iz belokranjskega narodnega zaklada I., Ljubljana: Katoliško tiskarsko društvo 1906, p. 230-234.
} 
rather, surrendered) all his acquired knowledge by spitting into his teacher's mouth, once encouraged to do so. ${ }^{55}$ Some other European, Asian, and African variants, as evidenced by Antti Aarne, also speak of a serpent touching a person's tongue, of a serpent's breath or speech (for example up a hollowed-out trunk) directed into a mouth or ears. Indian Jataka tales mention a mantra enunciated by a serpent, while serpents licked the ears of the Greek Melampus. The tales also mention the miraculous serpent's stone to be put under one's tongue. ${ }^{56}$

Even more interesting is the fact that there exist Siberian parallels. Yakuts for example hold forth that in an initiation ritual of a young shaman his teacher enumerates the different parts of the pupil's body, telling him the illnesses or demons to which each part belongs and what its healing properties are. After each piece of advice, he spits into the novice's open mouth. Similar to this is another Yakut tale about spiritual ancestors dismembering the body of a shaman candidate, while the teacher collects the patches of his flesh so as to reassemble them later. As he does so, he utters: "This is medicine against this or that illness" and spits into the novice's mouth. ${ }^{57}$ But the most frequent are the folk narrative motifs that connect the knowledge of the secret language with magical procedures, as for example with the consumption of the serpent's magic potion. One of the variants (folktale sample ATU 673) has it that a servant tastes a dish made from the white serpent intended for the king and starts to understand animal language.

In Kotlje in Carinthia, it was common knowledge that "if wanting to hear what flowers were saying, you had to eat a soup in which a white snake was cooked". ${ }^{8}$ The same procedure and effect was also known to medicine men in Serbia. ${ }^{59}$ Following the transcription from the Ukrainian Vinica, eating snake flesh enabled one to understand the speech of plants and, furthermore, what illness each plant was for ${ }^{60} \mathrm{~A}$ similar message can be found in the Upper Carniolan tradition, in Tunjice close to Kamnik, namely that whoever "licks a white snake, becomes all-knowing". ${ }^{61}$ Following the Slovene imaginary, the white snake is the mother of all other snakes, and she can be summoned by playing the flute and reading "black (magic) books". ${ }^{62}$.The connection between the snake and magic incantations acquires an additional meaning if we bear in mind that the latter were often compositions made up of nonsensical words. Moreover: towards the end of his life the Slovene snake king Babylon retreats, going down the rivers and streams into the Babylonian tower, which besides being a setting of the Biblical confusion of languages, is perceived to be an evil place of sorcery.

\footnotetext{
${ }^{5}$ Wilhelm Heinrich Roscher (Hrsg.), Ausführliches Lexikon der griechischen und römischen Mythologie, Bd. 1.2, Leipzig 1890, pp. 1686-1688. See also: Čajkanovič, SD 2, 439-440.

${ }^{56}$ Aarne 1914, p. 30.

${ }^{57}$ Gavril Xenofontov, Sibiřšti šamani a jejich ústni tradice, Praha: Argo 2001, p. 43 (Edice Capricorn, Svazek 7).

${ }^{58}$ Franc Kotnik, Blagoslov zelišč na kres in čar kresnic, Etnolog 15 (1942), p. 1.

${ }^{59}$ Radenković 1996, p. 23.

${ }^{60}$ P.P. Čubinskij, Trudy etnografičesko-statističeskoj ekspedicii v zapadno-russkij kraj, T. 1, Vyp. 1, Sankt Peterburg 1872, p. 210.

${ }^{61}$ Möderndorfer, p. 238, no. 1803.

${ }^{62}$ Tušek, Pripovedke iz Martiniverha. Od bele kače, Slovenski Glasnik 1 (1858), fasc. 2, pp. 80-81.
} 
We have already mentioned that the serpent, like a bird, is a guardian of wisdom. This can be seen, for example, from the very structure of the fairy tale type AaTh 670: at the beginning of the story, the serpent gifts the hero knowledge of the animal language, while in the denouement it is a bird (a rooster with its hens) which helps him solve his predicament and keeps him alive. The Bible (Matthew 10:16) and Slavic Apocryphal literature also granted the serpent supernatural knowledge alongside the negative properties. Of all the animals of the Biblical Garden of Eden, it was only the serpent that could compare in stature with Adam and Eve. With its intelligence and craftiness, not only did the serpent beguile Eve, but also God himself, who could not have foreseen such an outcome. He was punished by the loss of human characteristics - upright posture and a language comprehensible to humans. Since then, he always has to crawl on his belly. ${ }^{63}$

The serpent from Eden was neither an animal nor a human being. He occupied the in-between space and could be compared with the figure of the trickster in many European and non-European mythologies. The trickster is a fraudulent (anti) hero who, in going against an unyielding status quo, makes a move that triggers a fatal landslide of events. The fraudulent serpent (which is how Slovene poet Prešeren referred to him) is therefore, intentionally or unintentionally, the driving force of development, whatever that might be.

Serpents spend winters below the ground, which is what makes them both creatures of our and the "other" world. Those who hunt snakes with bare hands, have, according to Serbian folk religion, the power of prophecy. ${ }^{64}$ In the Slovenian folk oral tradition, a white serpent has the ability to fly through the air, while making a particular whistling sound. ${ }^{65}$ Both of these features make it resemble the figure of the bird. According to some versions, the voice of the white serpent is similar to the whistling noise of a dragon.

The explanation that the knowledge of animal language is acquired as the result of consuming a serpent's heart or liver was known to the Greco-Roman philosopher Philostratus at the turn of the $3^{\text {rd }}$ century. ${ }^{66}$ The subsequent development of the story about the impact of the snake soup is illustrated by the Norse Edda and Völsunga saga, which came into being in the $13^{\text {th }}$ century, although based on an older oral tradition. Both feature the dragon slayer Sigurd, who accidentally swallows a few drops of juice or soup made of fried dragon's heart, and immediately hears a conversation between two birds. They warn him of the dangers that he will soon encounter. Similar is the course of events in the German Thidreks saga from the late $12^{\text {th }}$ or early $13^{\text {th }}$ centuries. One of the episodes in the 5 th book of Gesta Danorum of the historian Saxo Gramaticus (1150-1220) describes a man by the name of Erik, who after eating a soup made of black serpents, masters the language of wild animals and domestic cattle. ${ }^{67}$ All the essential elements of the subse-

\footnotetext{
${ }^{63}$ Robert A. Segal, The Blurry Lines among Humans, Gods and Animals: The Snake in the Garden of Eden, RMN The Retrospective MethodsNetwork Newsletter, Special Issue, No. 10, Summer 2015, p. 111.

${ }^{64}$ Tihomir Djordjević, Priroda u verovanju i predanju našeg naroda, Srpski etnografski zbornik 72 (1958), No. 2, p. 180.

${ }^{65}$ Novak, Narodne pripovedke iz Podbrezja. Od bele kače, Slovenski Glasnik 1 (1858), fasc. 2, p. 113.

${ }_{66}$ Aarne 1914, p. 64.

${ }^{67}$ Timothy Bourns, The Language of Birds in Old Norse Tradition, M.A. Dissertation, University of Iceland 2012, p. $42,44$.
} 
quent variations are already present in this saga, but from that point on, the white serpent is mentioned instead of the black one.

The Irish tradition, differing from the above examples only in small detail, tells of Fionn MacCumhail, who, following the orders of his master, caught a miraculous salmon from the pool at the foot of a tree shedding hazelnuts of wisdom. He made a soup out of fish that had fed on these nuts, and in doing so he burned his finger. He quickly put it in his mouth to alleviate the pain, and immediately gained all wisdom, including the language of animals.

The secret language as a source of deepest wisdom also features in the myth of the Nordic god Odin. Animal language, however, does not get explicit mention there, but rather the language of runes, a type of letters that carries a linguistic as well as supernatural significance. Odin received this knowledge from the beyond in the self-sacrifice ritual, when for nine days and nights he hung off a branch of the World Tree, pierced with a lance and deprived of food and drink (Hávámal 138-139). He dedicated the sacrifice to himself, and this kind of self-sacrifice is reminiscent of initiation procedures of the Siberian shamans, the goal of which is coming to know the language of nature.

The transcription of the poem Hávámal is dated back to the $13^{\text {th }}$ century, but some of its passages (including the one of our episode) are at least a few centuries older, given the fact that the cult of Odin can be traced back to the $4^{\text {th }}$ century. Christian influence is already discernible in the late medieval versions, especially in the iconography of Odin's and Christ's (self)sacrifice. Nevertheless, the shamanistic substrate has survived, since Odin has the ability to transform himself into different animals, especially the eagle and the serpent. To some extent, this connects him with the complex of classical Siberian shamanism. But it remains difficult to be sure whether this typological similarity results out of generic links, since these remain under-researched..$^{68}$

The core of the initiation rite of the Siberian Samoyed peoples, for example, consists of a ritual boiling of the body of the future shaman in a cauldron. The dramatic description of the initiation ceremony by one of the Samoyed (Nganasan) shamans ends with the vision of a rock cave, in which a blacksmith dwells. This man seizes the newcomer, cuts his head off and boils parts of his body in a huge cauldron. It appears that the body contains more bone and muscle as would be the case in a common man, which signifies a predestiny to the calling of the shaman. The blacksmith then recovers the body to its original state, with the difference that he implants a new set of eyes into the shaman that will allow him to henceforth see fully during the rituals, and drills holes in his ears for him to hear and understand the language of plants ${ }^{69}$.

In a similar story of the Indian Baiga tribe, the body of the shaman is appropriated by demonic witches during the process of cooking. By taking it, they would also acquire his supernatural abilities. The shaman's brother and son were nevertheless able to acquire for

\footnotetext{
${ }^{68}$ Bourns, pp. 66-68.

${ }^{69}$ Clive Tolley, Shamanism in Norse Myth and Magic, II., Reference Materials, FF Communications, Vol. 297, Helsinki: Academia scientiarum Fennica 2009, p. 49-51. See also: Anna Leena Siikala, The Rite Technique of the Siberian Shaman, FF Communications, Vol. 220, Helsinki: Academia scientiarum Fennica 1978, p. 184.
} 
themselves a small meal and thereby preserve his knowledge for the benefit of humanity. The shaman in this story assumes the place of the "white serpent" in the role of the magical sacrificial animal, while the cooking process illustrates his physical and spiritual transformation. By sacrificing his old body, the shaman acquires a new, more perfect one. You could say that in this process he "snakishly" drops his old skin.

The hero being dismembered and then revived is also a known motif in the Greek myths of Orpheus, the Syrian Adonis, and the Egyptian Osiris. In the case of the Thracian god Dionysus it is mentioned that the Titans cooked him in a cauldron and then shared the dish amongst themselves. The three-legged cauldron thus became one of the identifying marks for Dionysus. The same motif also often crops up in fairy tales. ${ }^{70}$ According to one Russian fairy tale, a boy learns to understand the language of the birds after being thrown shaman-like into the hot cauldron three times by his forest teacher. ${ }^{71}$ Other tales describe the cauldrons of demonic witches, in which they cook their victims. In the European and the Slovenian environment, this idea is known in a somewhat more veiled and ironic form through the motifs of the "Old wife's mill." It is evident from folk storytelling and the painted beehive panels that the grinding mill stones crush the body of an old woman only to have her regenerate into a maiden that very moment. ${ }^{72}$ In many of these cases, however, the original initiation context has been completely lost.

\section{THE CODE OF THE FERN}

Slovenian farmers believed that domestic oxen can feel and respond like humans, even though they are incapable of human speech. Their conversations, according to Slovenian folk interpretations, can be understood only once or twice a year, at Christmas or at Midsummer night. This was also known elsewhere in Europe, since Midsummer and Christmas time were congenial for all kinds of divination and prophecy. ${ }^{73}$ The behaviour of certain animals in the Czech countries (these would have included animals such as horse, bull, cow, pig, dog, cat, wolf, rabbit, viper, mouse, cock, hen, cuckoo, magpie, crow, sparrow and pigeon) could be seen to carry prophetic significance. ${ }^{74}$ Happiness or misfortune was predicted also by the mere act of their appearance on certain days of the year.

The voices of domestic livestock would have been momentarily comprehensible particularly to someone who, either on Midsummer or Christmas night, had a fern seed on his body. Some would have picked the seed (or rather the spores) precisely for this purpose, but it may also have been the case that the spores accidentally fell into one's

\footnotetext{
70 Vladimir J. Prop, Historijski korijeni bajke, Biblioteka Raskršća, Sarajevo: Svjetlost 1990, pp. 150-152.

71 Prop, p. 158.

72 Niko Kuret, Babji mlin, Slovenski etnograf 25 (1955), pp. 171-206.

${ }^{73}$ Niko Kuret, Praznično leto Slovencev. Starosvetne šege in navade od pomladi do zime, Prva knjiga, Ljubljana: Družina 1989, pp. 417-418.

74 Václav Frolec a kolektiv, Vánoce v české kulture, Praha: Vyšehrad 1989, p. 83.
} 
clothes or footwear. ${ }^{75}$ Slovenian shepherds and servants would have gone and lain on fern in the woods on midsummer night, or would have made their beds with it in the barn next to the livestock. It was also advisable to put the seed of this herb into one's ear. ${ }^{76}$ Other interpretations hold that it was possible to hear the speech of oxen, cows, and horses at the point of one finding a space in the barn under the seventh beam. ${ }^{77}$ This way the person would have learnt of the events coming his way for the remaining part of the year. Eavesdropping on livestock was conversely also dangerous. Animals were not allowed to notice you were eavesdropping; else your life would have been endangered. ${ }^{78}$

Irish legend has it that the fern was cursed by St. Patrick, because it gave shelter to snakes. Since then, its growth has been seedless and blossomless. ${ }^{79}$ According to some medieval interpretations, however, the fern seed did exist, but it was invisible. This formed the basis for concluding that even the holder of such seeds can become invisible, or even that whoever treads on the ferns gets lost. The plant was also popularly known as an effective tool in searching for treasures. Some of the treasures would "open", according to folk belief, only once every hundred years, on Midsummer night. ${ }^{80}$ In the same way that the power of the fern grain could easily do away with the barrier between human and animal languages, it could also break any lock. Therefore, it was able to break the shackles of trapped ghosts and cursed souls who would have guarded the buried treasures. "The lifting of treasures" was a popular narrative motif in European folklore, bearing witness to the fact that such attempts were truly done on a massive scale. This trend, however, was officially banned in the $18^{\text {th }}$ century as a branch of black magic (magia demoniaca), or more precisely, necromantia.

In Slovenia, the same characteristics that were attributed to ferns were also ascribed to the fictional "rainbow root." The Serbs' word for this magical herb is raskovnik, while Russians and Ukrainians call it razryv trava. Stories of this root or grass are well known across Europe and can be traced back in the past all the way to Pliny's classic work Naturalis Historia $(18.10,25.05)$. It was unknown where rainbow root grew, thus the only way to obtain it was through trickery: the entrance to the trunks of old trees, where black woodpeckers nested, was closed with nails, and setting free the imprisoned young birds would force the woodpecker to bring the root, which in turn opened all doors.

This role was given to woodpeckers or other birds particularly in the West Slavic folk tales, while in the east, amongst the Balkan Slavs and in eastern Ukraine, it was the hedgehog and turtle that would have assumed the same role. In Dalmatia and the Russian north, it is the serpents who are the bringers of the miraculous root. In the Old Slavic language, the etymologies of the word hedgehog and a serpent are related, while both

\footnotetext{
${ }^{75}$ Agapkina, Paprat, in: Slovenska mitologija: Enciklopedijski rečnik, Svetlana M. Tolstoj in Ljubinko Radenković (ur.), Beograd 2001, p. 416.

${ }^{76}$ Števan Kühar, Národno blágo vogrskij Sloväncof, Časopis za zgodovino in narodopisje 8 (1911), p. 64; Möderndorfer, pp. 102-103, 312.

77 Möderndorfer, p. 324.

${ }^{78}$ Kühar, pp. 64-65.

${ }^{79}$ Lenore Wile May, The Economic Uses and Associated Folklore of Ferns and Fern Allies, Botanical Review 14 (1978), No. 1, p. 493.

${ }^{80}$ Kuret, p. 417.
} 
are also subterranean creatures. ${ }^{81}$ Once again, the typology of animals associated with plant magic, essentially narrows down to the basic pair: bird - snake. This duality is also reflected in the common saying "Neither a bird, nor a mouse."

Anthropomorphic characteristics were attributed to plants such as ferns, including the highly respected mandrake: their head, torso, limbs were distinguished and even their gender was determined. To further emphasize the plant's physical features, the root of the fern was cut in the shape of a palm with fingers. Therefore, the name Slovenes gave it was "Janže's hand", probably taken from the German Johannishand ${ }^{82}$. The mandrake distinguished itself from the fern mainly by the fact that its bell-shaped leaves and cleft root contained hallucinogenic ingredients (alkaloids), which of course only contributed to its reputation. Perhaps ferns were just a convenient stand-in for the mandrake, which grows only along the Mediterranean coastal strip.

As early as the end of the $17^{\text {th }}$ century, Slovene naturalist Valvasor already reported the different characteristics of ferns and related superstitions: "I have myself known someone in this country of ours who on St. John's Eve [...] would often go out looking for fern seeds with his magic ceremonies, and then put them to all kinds of inadmissible ends. A few years ago, however, he came to a miserable end by his own hand". ${ }^{83}$ The destiny of sorcerers can indeed only be so; the Bible predicted the outcome of disease, insanity, and premature death. Some sources relate how the pickers had to be naked and that they would look for ferns at crossroads in particular. ${ }^{84}$ The blame for the fact that such practices spilled across into the $19^{\text {th }}$ century can partially be laid at the doors of science, which was unable to explain the reproductive cycle of ferns until as late as 1851, when the German botanist Wilhelm Hofmeister finally succeeded in doing so.

Valvasor noted with some indignation that Satan had spread these superstitions across almost all European lands, "amongst those who have forgotten God, thus promising the students of the "Black School" as well as thieves and bandits marvellous effects from the seeds of this plant, such as opening locks so as to enter all closed chambers and other such sordid business. This is what draws the irredeemable souls in John the Baptist's night (Midsummer) to roam to places with a lot of fern, and with incantations on their lips pick it or even its seeds". ${ }^{85}$

According to popular belief, the fern blossoms, ripens and bears seeds in the middle of Christmas / midsummer night. All this happens within an instant, because no sooner does it happen the blossom disappears. It shines forth in a light-blue colour, though occasionally sources claim the light is dark red. According to Slovenian and European folk traditions. there are some miraculous trees (e.g. linden or walnut) that can also, in the same way as fern, turn green instantly, blossoming forth on Christmas and for St. George's day ${ }^{86}$

\footnotetext{
${ }^{81}$ Ljubinko Radenković, Raskovnik u krugu sličnih biljaka, Slavic Gate kapija@narod.ru 2000-2001.

${ }^{82}$ Ivan Navratil, Slovenske narodne vraže in prazne vere, Letopis Slovenske Matice 1896, p. 19.

${ }^{83}$ Valvasor, I, pp. 359-360.

${ }^{84}$ I(van) Tušek, O čarovnih zeliščih, Slovenski Glasnik 1863, p. 78.

${ }^{85}$ Valvasor, I, p. 369.

${ }^{86}$ Šmitek 2012, pp. 13-14; 52.
} 
Since fern can never actually blossom, nor does it have real seeds (only a type of spores on the inside of the leaf of the size of poppy seeds), all these magical instructions present no more than empty wishful thinking for, and belief in, the unattainable. However, we are not interested here in the effects of the ritual, but rather in its structure. If we accept that the ritual is a way of communication with the aid of signs and symbols, it is possible to recognize some of these and decode them.

From the examples given thus far, it can be concluded that the knowledge of bird or wild language is never transmitted by the bird, but always by the serpent. Insofar as some European black magic texts mention that in order to master the bird language it is necessary to eat the heart of a winged animal, they do so by drawing on Jewish occultism. The influence of the Jewish Kabbalah and Arab magical thinking came relatively late to Europe, in the $13^{\text {th }}$ century with the manuscripts and later prints, such as Liber Iuratus Honorii, and Liber Visionum, amongst others.

The original European tradition, which is of course older than the Middle Eastern influences, emphasizes the power of the serpent who, either through his heart, saliva, or when cooked in a "soup", that is to say with a category of something liquid or wet, transfers the language of wild and partially also domestic animals onto humans. In the northern part of Europe, the consuming of a heart of a certain animal along with drinking intoxicating drinks was a way of preparing oneself for the experience of a trance, helped along also by singing or music. The patroness of such rituals was the goddess Freya, and it was mostly (but not exclusively) women who took part in them. Men's method of achieving the same goal was retreat and asceticism.

At the same time, but probably somewhat later, a special magical procedure for understanding the language of domestic animals was developed, and it was revealed by the fern seed once it was sufficiently $d r y$ to fall off the leaves. We are thus confronted with two models, which oppose each other in terms of symbolism. The principle of binary oppositions does not end here, however, since it is already built into the very tissue of fern. In serving sorcery and magic, the fern plant was a marked antipode of God's will and blessing. It enabled access to cattle's language and in those instances where God was stingy in terms of benevolence.

While the fern seed along with the mythical flower is a symbol for dryness, this cannot be said of the plan's root, which typically lies in the shady moist soil. In symbolic terms the upper part of fern and its roots coincide with the opposition bird-snake. This is reminiscent of the iconography of the World Tree, where a bird nests in the crown and dominates the sky, while the serpent hides at the roots in his underworld. Together, however, they constitute a whole and are linked through a reversible relationship. According to Pliny (Naturalis Historia, $1^{\text {st }}$ century), the serpent is born out of a mixture of the blood of certain bird species. The same author also describes the basilisk, a hybrid creature that features in medieval depictions as having a serpent's body, a rooster's head and wings of a bat.

In the way that the fern's root is connected to wetness, so too is the serpent. We need only to remind ourselves of folk tales that depict the serpent as lying curled up in a ball at a water source, or show him as stealthily coming to drink milk from cows' udders. In 
cosmogonical myths, serpent-like creatures inhabited primordial oceans, representing the dominance of primordial chaos, as for example, the Greek Hydra, the Hebrew Rahab, the Nordic Midgard, the Indian Ananta and probably also the Mesopotamian Tiamat. When the mythical hero conquered the dragon, the water supplies the monster held in his power were suddenly freed.

According to the Bible, the serpent is a symbol of evil, and the fern, or rather its spores and its (fictional) flower, is what protects people against this evil. Such a dichotomy is clearly demonstrated by a Slovenian folk tale, in which fern grains enable a servant to follow the conversation between two oxen, finding out how to save his master from the bite of a poisonous snake.

We have established therefore that the fern root could represent a snake. The energy of the serpent, however, is directed upwards, which is symbolically captured also by the pointy hats of wizards and witches. This also explains why in some places, on midsummer night, people gathered fern by uprooting it entirely from the earth. This was not an easy job, because the root accounts for the major part of the plant and is very spread out. However, it was only an uprooted rather than mown fern, tucked into the roof that could protect one's home from a severe thunderstorm and lightning. With the same intention, pulled-out tufts of ferns would have been hung indoors.

The Slovene inhabitants of the Zilja valley (Zillerthal), for example, used to say that a fern thus picked had a golden ring at its tip. ${ }^{87}$ All across Europe, this item of jewellery was held to be a powerful magical protective symbol and played an important role in fairy tales. In medieval witchcraft guides it is said that the Jewish King Solomon received such a ring as God's gift to fend off demons. The fern with a gold ring therefore suggests something demonic and wild (snake), but also something that can control its strength (ring). People knew how to turn these contradictory forces to their own advantage along the principle of "fighting fire with fire".

Unlike the roots, the foliar parts of fern growing above the ground were harmless. They were used for bedding for farmyard animals, and on Midsummer night they would be scattered over the floors in farm rooms for John the Baptist to stay over and protect the house from a ball lightning. The Karst peasants also used to pin it over the hearthplace and clear out the ashes with it, before lighting the holy fire (oak stump) for Christmas. In this sense, the fern was a symbol of warmth and familiarity. The family residence was thus seen as a safe bird's nest. As protection against hostile and destructive night creatures, the fern found its place on the portals of some farmhouses in the Karst. Two of its stalks are carved into one of the stone entrances, each with 17 leaves, which amounts to 34 or the magical number $7(3+4){ }^{88}$

\footnotetext{
87 Vinko Möderndorfer, Verovanja, uvere in običaji Slovencev, Druga knjiga: Prazniki, Zadružna knjižna izdaja, Znanstvena knjižnica 5, Celje: Družba sv. Mohorja 1948, p. 311.

${ }^{88}$ Boris Čok, Kamnoseško izročilo o znamenjih na portalih in kolonah po Krasu, in: Katja Hrobat Virloget and Petra Kavrečič, Nesnovna krajina Krasa, Koper: Založba Univerze na Primorskem 2015, pp. 122, 125.
} 
The Slovenian tradition on ferns contains symbols that can be linked into two series based on the fundamental nature-culture opposition, from which a host of other binary oppositions emerge:

earth - fern root - regularly available - serpent - water - wet - wilderness - wild animals - nature

sky - fern seed / flower- rarely available - bird - fire - dry - home - domestic animals - culture

The sequence of components is irrelevant, since they can appear in ever new combinations. According to this scheme, culture is something fragile and transient, not unlike fire, which can blow out any time or a flower which fades away.

\section{MIMICKING THE DEVIL}

While understanding animal language was made to be so difficult for human beings so as to be nearly impossible, for animals, it was easier to respond to human voices. Some caged birds, for example, could be taught to imitate individual words and melodies, and pets could read human commands. Inja Smerdel's research has shown that as late as in the 1970s, Slovene farmers, while leading yoked oxen, gave them commands in the form of a harmonious melody. They would also spur them on by more or less monotonous singing and whistling. ${ }^{89}$.Therefore, what mattered was not only the outer form of what was said or sung, but also its context: how it was conveyed and who was the enunciator: the master, his wife, child, or a stranger.

It is easier to understand and see the logic behind the existence of everyday communication with domestic animals with which people had a close living and working relationship, while more enigmatic is the human interaction with the world of wilderness. In comparison to the whistling to oxen, which had a mobilizing - even therapeutic - effect on the animals, whistling to crabs must have seemed like real sorcery. Such sentiments were also lent credence by Valvasor:

It is truly the best crabs of this land that love the Rivers Krka and Kolpa, and while ordinarily they are caught with fish traps as well as in a variety of other ways, there is a special, even funny, way of catching the ones from Kolpa. An earth worm is tied onto a stick and the stick immersed in the water, bringing it close to holes, which are mostly in the hard rocks. Then whistling a certain tune and a strange melody so the crabs come out of their holes, they use another pole, which is cleft at one end, to grab hold of the crabs and pull them out [...] I found this rather funny and a bit fairy-tale

\footnotetext{
${ }^{89}$ Inja Smerdel, Zvok besed, glas zvokov. O kulturi sporazumevanja z delovnimi voli na Slovenskem, Etnolog 19 (2009), p. 37-77 (especially, pp. 54 in 65-71).
} 
like, when I heard they whistled to them. But they assured me that they would scarcely come out of the holes if it were not for the whistling; no sooner do they start whistling than the crabs crawl out. Since one person can whistle better than the next, there is often a competition between the whistlers, testing each other who can best whistle the crab tune [...] And so I asked an old Croat90 named N. Polakauich [...] don't crabs also come out without the whistling? And he said: "No. They don't." It only rarely happens that a crab comes out unless you whistle; because the water is crystal clear, and the crab can see you. But the minute you whistle their tune, they emerge out of many holes. If by whistling you get a hundred crabs, without it you will not even get six. ${ }^{91}$

In this way, they would catch crabs close to Vinica, Pobrežje and in the surrounding area, and according to Valvasor's data also along the rivers Dobra, Mrežnica and Korana in Croatia and across Turkish lands. In his monograph on Carniola, Valvasor went as far as to publish musical notation for the whistling sound. ${ }^{92} \mathrm{We}$ should further note that in popular lore it was the devil who summoned crabs whistling, so they would come out of the water and graze in the field. ${ }^{93}$ Professor Stane Mikuž, born in Šmarje next to Grosuplje, wrote down a story he had heard from his mother in his youth about a crab master. I relate it here in a condensed form:

At night, the village boys went crab catching, because that was when they would find them grazing in the grass. They collected them in a basket, including one which was exceptionally big. Returning home, they heard a call from the stream: "Give back the giant crab!" They did not obey, giving rise to two more summonses, the last one being so loud that spruce trees shivered in the woods. Then they dropped the basket into the ferns and came running into the village out of breath. ${ }^{94}$

From this story, it is clear that the crabs were in the hands of a supernatural night creature. That the boys threw the basket of crabs into the ferns cannot be coincidental. It could mean that they returned the crabs to whoever is symbolized by this magic plant (or to whom it belongs). The Devil assumed this role from the original mythical lord of the animals, which the Slavs believed to be a forest spirit (Russian Lesovoj, Ukrainian Lisun or Polisun), or a white, or grey, or limping wolf, or an anthropomorphic figure of a grey-haired old man, "wolf's shepherd".

\footnotetext{
${ }^{90}$ Often Valvasor would refer to the local inhabitants of Bela Krajina simply as Croatians.

91 Valvasor III, p. 453.

92 Valvasor XI, p. 147.

93 Janko Lokar, Vsi pojte rakam žvižgat!, Etnolog 15 (1942), pp. 95-96.

94 Stane Mikuž, Nekaj narodopisnih drobtinic, Slovenski etnograf 16-17 (1963-64), pp. 223-224.
} 
According to the experts, the wolf or the old man can be seen as representations of the Slavic god of the underworld and animals, Veles. His replacement with the devil meant the demonization of this pagan god by the Christian Church. This was common practice on the part of the Church, going back as far as the Apostle Paul. At the same time, however, this practice also gave a basis to apocryphal interpretations in which God had created useful animals and nutritious and medicinal plants, while the devil, in mimicking God, did not manage to create anything other than a wolf (a synonym for all beasts), a snake (the embodiment of sin) and other harmful and poisonous animals.

Since the Bible does not actually describe the devil's physical appearance anywhere, the devil, by a type of analogy, assumed the features of Pan, the Greek god of animals and wilderness, of herds and shepherds. However, Pan, too, together with his Roman counterpart Faun, had a long line of predecessors who shared the role of the master of animals. A list of them would stretch all the way back to the beginnings of human history. The earliest depictions show them in the company of birds, griffons, or serpents. From the late Mycenaean age, there is even a winged creature of this type with a bird in each hand, while in the ancient Iranian variant it is shown with two serpents. ${ }^{95}$ Roman Gaul gave rise to depictions of the horned god (Cernunnos), who is also accompanied by serpents. This character - with a snake in his hand and surrounded by forest animals - is also the character adorning the outer wall of the cauldron from Gundestrup ( $1^{\text {st }}$ century). Lutz Röhrich traces the roots of the master of animals to the eastern Mediterranean and Minoan Crete cult of Artemis. ${ }^{96}$

Pan was a quite unhuman-like, ugly creature; he had goat's legs and a hairy body. His strong voice was frightening and could throw people into panic, as in the Slovenian tale above. According to one mythological story he was the first to invent the reed pipe, a shepherds' instrument, named after him as Pan's pipe. Annual celebrations dedicated to Pan which took place in the natural environment were very popular. There was a fertility significance attached to them. On the outside, there is one creature in Slovenian mythology exactly like Pan: the mountain and forest elf called Čadež. He is half man-half goat, and can either be benign or dangerous. When in his own forest abode, he likes to confuse and misguide a traveller.

Even the devil was a creature of nature and night, covered in black hair, with a horned goat's head, bat wings and a long tail. It could morph into different animals or humans. ${ }^{97}$ Like Pan, he was the master of animals. The Carniolans of Valvasor's time would relate how he had marked out his herd of dormice, whereby all who were mature enough had a torn or notched ear. Nonetheless, the devil did not take over the flute from Pan. Following strict Christian criteria, the flute was not for him to have, since it symbolized the sphere of culture. The only means of communication he could avail himself of was whistling,

\footnotetext{
95 Roger Hinks, The Master of Animals, Journal of the Warburg Institute 1 (1938), No.4, pp. 263-265; Jacqueline Chittenden, The Master of Animals, Hesperia, The Journal of the American School of Classical Studies in Athens 16 (1947), No. 2, pp. 89-114.

${ }^{96}$ Lutz Röhrich, Die Sagen vom Herrn der Tiere, Internationales Kongress der Volkserzählungsforscher im Kiel und Kopenhagen (19.8.-29.8. 1959), Berlin 1961, pp. 343-347.

${ }^{97}$ Jeffrey Burton Russell, Lucifer: The Devil in the Middle Ages, Ithaca, N.Y.: Cornell University Press 1984, pp. 67-71.
} 
the primordial voice of wilderness resembling a "bird language", and indirectly the language of animals in general.

Today, we know that the origins of the flute date back to when shepherds and herds were not even on the horizon. Among the animals depicted in the cave Trois Frères (dating $15,000 \mathrm{BC}$ ), is a flute player dressed in hides. The Stone Age hunters, the ancestors of today's man, used pipes made from hollow bird bones in the late Palaeolithic age. The one from Geissenklösterle cave in the Swabian Jura is between 42,000 to 43,000 years old. It is made from the bones of the mute swan (Cygnus olor), whereas the musical instrument from the nearby cave Hohe Fels, which is between 35,000 to 40,000 years old, is made of the wing bone of the griffon vulture (Gyps fulvus). In short, the very first pipes could not have been more "bird-like".

According to one of the variants (in fairy tales of the type AaTh 670), the transfer of linguistic knowledge from the snake onto man takes place by way of a narrow tube conducting snake saliva into the hero's mouth. Fairy tales connect this procedure with human anxiety related to touching a poisonous snake's throat with the mouth. The deeper meaning of all this, however, is apparent from cases where the hollow gadget comes in the form of the shepherd's pipe. ${ }^{98}$ Perhaps the symbolism of the flute as a link between the animal and human languages is made even more explicit in instances where one brings the pipe close to his ear, and the snake whispers through it enabling him to understand the animal language. ${ }^{99}$ It was important for this symbolism to be explicit; clearly, it was also present in the minds of both storytellers and listeners. For our comparative angle, it is also interesting to note that the Middle English word for the pipe, the whistle, also carried the meaning of snake's hissing. ${ }^{100}$

The pipe as a mediator of snake's knowledge enabled humans to communicate also with the underworld and the dead. A Sardinian fairy tale, for example, speaks of a shepherd opening a secret passage into the otherworld and the underground treasury by whistling a precisely set melody. ${ }^{101}$

According to the already mentioned Slovenian stories, the sounds of the flute could summon the White Snake, while this "mother of all snakes" responded with whistling. This also indicates a kind of compatibility between playing the flute and whistling, which differ from each other only in that the first represents a sound of culture and the other a sound of nature.

When, following Valvasor's telling, the black fiend led the dormice to graze in the forest, sounds of snapping, lashing (of the whip) and whistling were heard. It was best to flee immediately, since "the devil ran over anyone who did not get out of his way when he whistled". ${ }^{102}$ When people went hunting for crabs, they could emulate the devil's whistle,

\footnotetext{
${ }^{98}$ See, for example, Petko Domazetovski, Narodni skazki od Dolni Drimkol, Struga: Društvo za nauka, kultura i umetnost »Brača Miladinovci« 2000, pp. 263-268 (no. 41).

${ }^{99}$ For example, Kuzman A. Šapkarev, Izbrana dela, Knj. 5, Skopje: Misla 1976, pp. 298-300 (no. 134).

${ }^{100}$ The American Heritage Idioms Dictionary, Houghton Mifflin Company 2002 (entry: whistle).

${ }^{101}$ Felix Karlinger, Jenseitswanderungen in der Volkserzählung, in: Schamanentum und Zaubermärchen, Heino Gehrts und Gabriele Lademann-Priemer (Hg.), Kassel: Eric Röth-Verlag 1986, p. 185.

${ }^{102}$ Valvasor III., pp. 438, 439.
} 
but had to be careful that the devil not hear them; else he would shred them to bits. On account of its connection with the demonic forces, whistling had negative connotations. "Požvižgati se na kaj (lit. to whistle on something)" to this day means to disregard or to not value something. Similarly, expressions such as "pofučkati denar (lit. to whistle money away)" used by Slavs, Romanians, and Baltic peoples do not carry positive meanings.

According to popular lore, the whistling devil took other animals out grazing, especially nocturnal and chthonic animals. With the same call, one native of Carinthia's Šmarjeta village summoned a herd of rats. ${ }^{103}$ A similar magical link also existed with the bees, for when "the bees swarm, (beekeepers) take an iron or copper pan, and hit it with a small stick while whistling, (and) the bees in a tree or a bush gather into a round lump [...]". ${ }^{104}$

The devil as a demonic night shepherd found his opposite in the figure of Christ surrounded by a flock of sheep (Christians), which he guarded against the wolf (Satan). Allegory of the Good Shepherd who sacrificed his life for his herd, was used in John's gospel (10.11-18), and it figured prominently in the early Christian figurative art. Besides this, God is comparable also to "the Lord of the forest" for having determined the habitat of each type of game (Psalm 104) and provided prey for them in the time of distress: "The young lions roar for their prey, seeking their food from God" (Psalm 104. 21).

Besides God, there were also other, more earthly aspirants for the position of the animal leader - Christian saints. Early Christian legends arising in the $4^{\text {th }}$ and $5^{\text {th }}$ centuries amongst the hermit monks in Egypt and Syria, and which spread throughout Europe a century later, described a more or less comfortable cohabitation of holy men with wild animals. These legends combine diverse components of folk religion with official church hagiography. However, on the whole, more than the role of the lord of the animals the saints took over the role of peacekeepers. They intervened particularly when the natural order was under threat, or when the boundary between man and animal was overstepped and it became necessary to restore the original state. ${ }^{105}$ In such instances, they would for example lock wolves' mouths with heavenly keys, defend the livestock, and erect fences around it, or in some other manner discourage bloodthirsty intruders.

When church legends broached this sensitive subject, they were scrutinized so as not to veer into heresy. Slavic apocryphal versions retained greater freedom. It was only in popular "heretic" interpretations that the saint himself sent a wolf over to attack a given domestic animal, thus turning from the saviour into a troublemaker. ${ }^{106}$ Offering sacrifices to the saints so as to defend grazing animals against wolves was partly in keeping with the pagan traditions: a common sacrifice in the Balkans was a black or mottled chicken, a hen or a rooster, while in Russia it was the wild rooster. ${ }^{107}$ It is interesting to note that even Valvasor in his writings refers to the folk traditions, but there is no mention

\footnotetext{
${ }^{103}$ Möderndorfer 1946, p. 243, no. 1857-1858.

${ }^{104}$ Mirko Rupel, Valvasorjevo berilo, Ljubljana: Mladinska knjiga 1951, p. 33.

${ }^{105}$ Dominic Alexander, Saints and Animals in the Middle Ages, Woodbridge: Boydell Press 2008, p. 4, op. 12.

${ }^{106}$ Mirjam Mencej, Funkcija gospodarja volkov v povedkah, zagovorih, verovanjih in šegah, Etnolog 10 (2000), p. 163-178.

${ }^{107}$ Mirjam Mencej, Volčji pastir v kontekstu dosedanjih raziskav na področju slovanske mitologije, Studia mythologica Slavica 4 (2001), p. 171.
} 
of saints. In the example, we have yet to give, the devil exercises full sovereignty over "his" wild animals.

Of course, we cannot blame Valvasor for being misled by some folk narratives and interpretations, despite his judiciousness. Much later still, the great naturalist Carl Linnaeus would for example write (in the tenth reprint of his Systema Naturae from 1758) that mermaids (sirens) were real beings (Homo sapiens monstrosus) and as such were relatives of humans and apes. When whistling to the crabs became synonymous with something mad and inefficient, humorous sayings became widespread: "Go and whistle to the crabs, go sing to the fishes" and "Quiet, so I can hear the crabs praying", as well as their further derivates "go play music to the frogs" and "go play to the fish". In Carniola, the expression was widespread in the $17^{\text {th }}$ century also in the sense of: "He went whistling to the crabs - he died", something that was also known to Valvasor.

Valvasor the naturalist was so keen to understand human communication with animals that he collected more data. ${ }^{108}$ With his description of Lake Cerknica he also wrote:

"... in addition to the fish there is also a vast number of leeches living here, and no sooner does anybody go in than they immediately attach themselves to his legs. Oddly enough, calling out a few specific words to them, these leeches at once surround the person. I first got to hear of this from the old fisherman Jernej Roženta (Jerne Roschenta), although I did not quite believe him, until, that is, I saw it with my very own eyes. He told me how the leeches would gather around the person no sooner he called out these words to them: 'Drink me, leech! Drink me, leech!' And so as to demonstrate for me to see, he went in alone, and, in the manner just told, cried out or rather sang out the words 'Drink me, leech', etc. Upon which I was astonished to see how the leeches crowded in upon him. And if he did not sing these words, only very few would come to him. And this happened in front of my very own eyes on October 1st, 1685". ${ }^{109}$

The leeches thus gathered could either be sold, or they would use them for themselves for medicinal purpose, for example in the cases of stroke or an epileptic fit ${ }^{110}$.

He asked his learned colleague, the German scholar Erasmus Francisci, for his opinion on whether the leeches came to man in a natural way, or because of the pact with Satan. His own understanding was that the cause lay in the "natural effect of certain words found in the Carniolan language, or rather of the voice or sound and melody accompanying them". ${ }^{111}$ In an extensive commentary, Francisci rejected this theory, saying that the sound and melody change in the medium of water and that therefore the same result could be

\footnotetext{
${ }^{108}$ Igor Cvetko in his discussion of Valvasor and sound already noted this, in Valvasorjev zbornik, Ljubljana: SAZU 1990, p. 311-322 (especially 317-319).

${ }^{109}$ Valvasor IV., p. 652.

${ }^{110}$ Vinko Möderndorfer, Ljudska medicina pri Slovencih, Inštitut za slovensko narodopisje, Gradivo za narodopisje Slovencev 1, Ljubljana: SAZU 1964, pp. 203, 205.

${ }^{111}$ Valvasor III, , p. 61.
} 
achieved simply by changing the speech or melody. The sound stimuli only warn the animals that the prey is close, which makes them move closer. ${ }^{112}$

\section{INVITATION FORMULAS}

We have thus shifted from the audio signals, such as whistling, to speech forms, for which people too thought they had the same beckoning effect. Staying with Valvasor, let us draw attention also to his note on how to lure a cricket out of his hole: "It is only with the Turks and along our border [probably he was thinking of the border in Bela Krajina-op. ZŠ $]$ that crickets are drawn out with certain words. I myself heard a Turk (an Uskok) boasting of crickets coming out of holes if he pronounced a few words. This would then be common with other Turks in Bosnia and Lika as well. The words are as follows: "Cricket, come out of your court! Your offspring wants to bite me." Then they would hurriedly come out, surprising anyone who had never seen such a thing before" 113 .

Other Slovenian regions were also familiar with short texts for summoning crickets out of their dwelling places. Slovenian and Kajkavian forms read: "Šuri (čuri) muri, go (come) out". At Dobrava near Kropa, children recited: "Mur, Mur, come out the cranny, let's eat some white dumplings! Come out, I'll get you a tune, and we'll go to the field to grow wheat! ${ }^{114}$. This is comparable to soliciting ladybirds to fly into the sky or asking snails to show their horns. Karel Štrekelj in his large collection of Slovenian folk songs noted many such examples, categorizing them amongst children songs. ${ }^{115}$ In some instances, these "songs" are remnants of Old Slavic ritual texts and are similar across the territory where Slavs had settled.

The ladybird was once considered a sacred animal, which is confirmed by its names: in Bela Krajina, she was referred to as God's ox, in Styria as a divine cow, Virgin Mary's pretty cow, God's heifer. ${ }^{116}$ On that count, it was commonly held that one should not kill a ladybird ${ }^{117}$. Superstitious people would put her on their outstretched hand, or on a finger, asking her: "God's pretty cow, darling creature, how many years am I to live?" or "Spark, rainbow, show me the path to heaven". ${ }^{118}$ They saw the answer in whether she flew high up into the sky or low towards the earth.

The snail (especially the black snail lazar) is a lunar symbol, which like the moon extends and hides his horns. In Styria, children would tease it: "Puž - muž, puž - muž, show your horns, else we'll destroy your house!" Other provinces too were familiar with similar texts. ${ }^{119}$ Because of its association with cyclical repetitions, it acquired an impor-

\footnotetext{
${ }^{112}$ Ibid.

${ }^{113}$ Valvasor III., 457.

114 Štrekelj, IV, 7992.

${ }^{115}$ Štrekelj IV, 7990-7993 (cricket), 7981-7986 (ladybird), 7994-8000 (snail).

${ }^{116}$ Möderndorfer 1946, p. 241, no. 1840.

${ }^{117}$ More about that: Zmago Šmitek, Mitološko izročilo Slovencev. Svetinje preteklosti, Ljubljana: Študentska založba 2004, p. 174.

${ }^{118}$ Štrekelj IV, no. 7983.

${ }^{119}$ Štrekelj IV, no. 7998.
} 
tant role in folk medicine in treatment against diseases. So, for example, Slovenes had an incantatory saying: "warts disappear - the snail's salivating over you", which was part of a healing ritual. ${ }^{120}$ In Serbian magical formulae, the snail featured as protection against snake bites. The attendant etymological figure plaziti-laziti (crawl-glide), with its typical poetic and harmonious composition points to an Old Slavic pattern with a ritual purpose. ${ }^{121}$

Thanks to Valvasor we also know that Slovenian peasant boys and shepherds, when a flock of cranes flew over them in the typical V-shaped pattern, called out: "Turn around in a circle, Kolobar, half forward, half backward, beware the wolf doesn't eat you! Around you go, around you go." At the same time, they would turn three times on the spot and, lo and behold, the birds immediately shuffled and it took some time before the patterned order was restored again. Mirko Ramovš suggested that the sung verses were a dance song with magical significance. ${ }^{122}$

According to popular belief it was not only the repetition of certain forms of speech and singing that affected the behaviour of animals, but also the sound of some instruments. The story of a musician, who warded off a pack of wolves at night by playing the fiddle or a bass, was well known. ${ }^{123}$ Valvasor too knew that music frightened the wolf away. ${ }^{124}$ Slovenian folk songs are familiar with the motif of a musician at the gates of hell who with the irksome sound of his fiddle or harp made the devil return his loved one.

We can recognize Orpheus in this figure who, according to the Greek myth, played on the lyre trying to save his wife Eurydice from Hades. Orpheus, of course, was not only a master musician but was equally well versed in magic and astrology and was a key figure in orphic mysteries. His music not only influenced the gods, humans and animals, but also trees and stones. Like Orpheus, the Slovenian musician descended into the underworld in search of souls, as if he were a shaman. ${ }^{125}$ However, he was not saving his wife, but one or more of his close relatives and was in most cases (as noted in over 30 written variants) successful. His fiddle was no ordinary instrument: it was made from bones picked from the cemetery, while the strings were woven from human hair. As some records compiled by Branislav Rusič show, in the Balkans there was a sense that the secret of the wild language was stored in the world of the dead. ${ }^{126}$ In this we can also glimpse the answer as to why it is the serpent, a creature from the underworld, who has access to this language.

There were other instruments beside the fiddle, such as the flute and horn, which were symbols of the afterworld, something we have already intimated with the example of the

\footnotetext{
${ }^{120}$ Möderndorfer 1964, p. 215.

${ }^{121}$ Biljana Sikimić, The Etymological Magic and the Etimology of Text, in: The Magical and Aesthetic in the Folklore of Balkan Slavs, Belgrade: Library Vuk Karadžić 1994, p. 79. See also: Ljubinko Radenković, Narodna bajanja kod Južnih Slovena, Beograd: Prosveta - Balkanološki institut SANU, p. 24.

${ }^{122}$ Rupel, Valvasorjevo berilo, p. 130. Mirko Ramovš, Ples v slovenski ljudski pesmi, Traditiones 27 (1988), pp. 84-85.

${ }^{123}$ Monika Kropej Telban, Tipni indeks slovenskih ljudskih pravljic. Živalske pravljice in basni, Ljubljana: Založba ZRC 2015, pp. 300-301.

${ }^{124}$ Valvasor III., p. 59.

${ }^{125}$ Zmago Šmitek, Poetika in logika slovenskih mitov: Ključi kraljestva, Ljubljana: Študentska založba 2012, pp. 211-213.

${ }^{126}$ Rusić, pp. 43 and 45.
} 
demonic shepherd. Additionally, Europe has a widespread tradition of a whistle made from of the bones of a murdered man, thus accusing the perpetrator with its sound ("a singing bone" in Slovenian folk songs and tales). The notation of a song about a fiddler from the Rezija valley at the gates of hell, whose melody too is very archaic, differs from the classic Orpheus pattern in that Santilawdic (Saint David) beeps, and blows in hell. ${ }^{127}$ Since Saint David is known solely in Wales, the name Santilawdić can relate only to the Jewish and biblical King David, the renowned musician and psalmist. He also had his place in other Slovenian songs and legends.

In one Macedonian fairy-tale, the hero plays to a serpent on a lyre, and in turn is reimbursed by having all his wishes fulfilled. ${ }^{128}$ It is worth mentioning here that Greek mythology attributes the invention of the lyre to the god Hermes, the companion of souls to the other world, originally the lord of animals and their shepherd. The origin of this figure goes back to the Babylonian cult of the Mother Goddess. Then Hermes was the serpent god, while in the Greek execution, he was symbolized by two serpents wrapped around an upright pole. The two of them together, the male and female serpent, signified the merging of opposites and a source of fertility.

People of all traditional cultures were able to imitate various sounds, be it for fun or for purely utilitarian purposes, as with hunting and ritual and magical procedures, and to a greater or lesser extent, they also imitated them in their music. Abstract music is perhaps only the last stage in this development from the initial imitation of animal sounds through the ritualized imitation for symbolic or magical purposes to even more sophisticated levels of symbolic imitation. ${ }^{129}$ One of the theories about the origin of human language is derived from onomatopoeia.

In addition to the pure audio there is also verbal onomatopoeia. For Slovenian ears, the swallow, for example, makes the sounds of čiri, čiri or ciciri, the partridge of $c i$, či the quali of petpedi and the magpie of $\check{s} \check{c} e k, \check{s} \check{c} e k, \breve{s} \check{c} e k$. In Slavic languages, the word cici for sinica (swallow) and its singing is particularly interesting. In this context, Biljana Sikimić pointed out the children's game known in Serbia with the non-expressive name "žmurke", whereas in Ukrainian folklore it is called cici baba and kucibaba. A similar lexical item ciciban exists among the South Slavs, in variants such as cicibaj, cicibag, cicigoj, cicikur, cicmiga, etc. ${ }^{130}$

We have already mentioned the propensity of birds to warn man or advise him. They have this role in ballads as well as in short children's songs. ${ }^{131}$ Sikimić has observed that such a "message" begins with similar formulae that can also be found in a number of

\footnotetext{
${ }^{127}$ Julijan Strajnar, Mitološke prvine v slovenski ljudski pesmi, Traditiones 19 (1990), pp. 169-176.

${ }^{128}$ Stefan I. Verković, Makedonski narodni umotvorbi, knj. 4, Južnomakedonski narodni prikazni, Skopje: Makedonska knjiga 1985, p. 346 (no. 74).

${ }^{129}$ Emily Doolittle, Crickets in the Concert Hall: A History of Animals in Western Music, Trans, Revista transcultural de musica/Transcultural Music Review 12 (July 2008).

${ }^{130}$ Petar Skok, Etimologijski rječnik hrvatskog ili srpskog jezika, Knjiga treća, Zagreb: Jugoslavenska akademija znanosti i umjetnosti 1973, p. 251 (entry: sjenica).

${ }^{131}$ Marjetka Golež Kaučič, Živalske pripovedne pesmi - vloga in pomen živalskih podob, Traditiones 31 (2002), no. 2 , p. 32 .
} 
nursery rhymes ("Sedi ban jareban, broji tice jarebice..."). ${ }^{132}$ Since many puzzles also begin with more or less the same lines, these fragments are most probably the residue of the old panslavic ritual texts, which found refuge in children's folklore once they lost their original purpose.

In a short paper devoted to this theme, Dušan Ludvik enumerated more onomatopoeic variants on ciciban from the Slovenian ethnic territory: fi-ce, ci-ci-fuj, si-suh, ce-pli-mal. All of these forms can be found in Štrekelj's collection of songs, arranged in a repetitive sequence, as even the great tit repeats the basic form three or more times whilst changing the melody. It is also important to note that similar imitations extend across to Austria and Germany, as in the example of $s i$-si or $z i$-zi-bäh. ${ }^{133}$. This presents the researchers with the task of a more detailed examination of the actual prevalence of these forms and a clarification of cross-cultural influences.

Polish $d z i w, d z i w$, which is the sound for imitating the voice of the sparrow, is similar to the Slovenian short and high-pitched bird sound čiv, čiv. It is at the same time an expression of wonder, derived from the already mentioned divz. Even closer to us is $z ́ i w, z ́ i w$ from Lower Lužica, and the Macedonian Bulgarian dživ, dživ. In Turkish dialect $d z ̌ i v d z ̌ i v$ means chirp, and civce or clvclk is the sparrow. ${ }^{134}$ Should such similarities in onomatopoeia of neighbouring and more distant languages be explained by a regional or an ethnic key?

The just mentioned Slavic-German parallel presents a special case, since it is generally true that in different cultural environments the voices of individual animals and thus also different species of birds are mimicked in different ways. In contrast, there are cases telling us the opposite is true, since very different cultures imitate the voices of certain animals, especially cats' meowing, the singing of roosters and the hissing of snakes, in astonishingly similar ways. This raises the question of whether we actually imitate what we hear or what we want to hear. ${ }^{135}$ And if the latter turns out to be true, then what is it that we want to hear in the songs of birds?

\footnotetext{
${ }^{132}$ Biljana Sikimić, Etimologija i male folklorne forme, Beograd: Institut za srpski jezik SANU 1996, p. 137 (op. 275), 138.

${ }^{133}$ Dušan Ludvik, Odkod Župančičev ciciban?, Sodobnost 42 (1963), no. 3-4, p. 332-334.

${ }^{134}$ Sławski, p. 231-232 (entry: divъ!)

${ }^{135}$ Asa Abelin, Imitation of bird song in folklore - onomatopoeia or not? Quarterly Progress and Status Report 51 (2010), p. 13-16.
} 


\section{KAJ PTIČI POJÓ? \\ O ŽIVALSKI GOVORICI V JUŽNOSLOVANSKI FOLKLORI \\ ZMAGO S̆MITEK \\ $\infty$}

Ena od najbolj prvinskih človeških želja je bila, da bi kot ptica poletel v nebesne višave. $Z$ enako vnemo pa si je prizadeval odkriti ključe razumevanja ptičjega petja, ki se je zdelo bodisi podobno glasbi ali jeziku. Jacques Derrida je postavil in argumentiral tezo o neustavljivi človeški potrebi po razumevanju, prevajanju in razlaganju zakodiranih sporočil. Toliko bolj je to veljalo za glasove ptic, ki so v mnogih starih kulturah veljale za nekaj posvečenega; bile so družabnice bogov, obdarjene z veliko modrostjo, znale pa so napovedovati tudi prihodnost.

Pripovedi o »ptičjem jeziku« iz različnih kultur in obdobij se strinjajo v tem, da je bil razumljiv le malokateremu človeku. Po nekaterih mitih je bilo takšno znanje junaku že prirojeno ali pa mu je bilo podarjeno kot božje povračilo za opravljene usluge. Med takšnimi božjimi izbranci sta bila npr. starogrški prerokovalec Tiresias in judovski kralj Solomon, medtem ko se je s prirojenim znanjem ponašal južnoslovanski Kraljevič Marko. Po krščanskih razlagah je bilo obvladanje vseh jezikov, človeških in živalskih, dano tistim, ki jih je prepojil Sveti duh, torej svetnikom in apostolom.

Krščanska interpretacija je junaku odrekla možnost samostojnega ukrepanja in ga popolnoma podredila božji volji. Po biblični tradiciji je Bog že ob izgonu prvega človeškega para iz raja onemogočil komuniciranje z bitji narave (živalmi, rastlinami), kasneje pa med gradnjo babilonskega stolpa pomešal še človeške jezike. Marsikdo, ki se ni želel sprijazniti s takšnimi zaprekami, se je začel ozirati po magičnih poteh, ki so predstavljale nekakšno nelegalno obvoznico. Magični obrazec se nam razkrije že v nordijskem mitu, zapisanem v Eddi in Völsunga sagi v13. stoletju, o junaku Sigurdu, ki si je pridobil znanje ptičjega jezika z zaužitjem kapljice soka iz pečenega zmajevega srca. V Gesti Danorum iz 2. polovice 12. ali začetka 13. stoletja pa je kot magični zvarek že omenjena juha iz telesa črne kače.

Ta motiv, ki je bil v ustnem izročilu še dosti starejši od prvih zapisov, nastopa tudi v pravljicah (AaTh 760) in je široko razprostranjen po vsej Evropi. Nekatere staroindijske paralele kažejo, da so se osnovne variante izoblikovale prav v tem delu Azije. Prenašalka jezikovnega znanja je v teh primerih kačja sapa ali slina. Jedro sibirskih iniciacijskih šamanskih obredov je prav identično: šamanovo pljuvanje v usta svojega učenca, ali pa (mentalno doživljeno) prekuhanje njegovega telesa v velikem kotlu, kot da bi šlo za pripravo nekakšne juhe. To dejstvo nam odpira okno v širši prostor evrazijskih lovskih kultur. Svojevrstno presenečenje pa je, da so nekateri tovrstni drobci vpleteni celo v starogrške mite o Glaukosu, Polieidosu in Pelopsu.

Čeprav se živalski jezik, ki ga je mogoče obvladati prek magičnih postopkov, marsikdaj imenuje »ptičji«, ga človeku lahko pokloni le kača. Ptica in kača sta 
čuvarki modrosti, hkrati pa tudi pogosta, če ne celo osnovna, magična rekvizita. $\mathrm{V}$ marsikakšnem pogledu sta si nasprotujoča simbola, ki pa lahko nastopata $\mathrm{v}$ reverzibilnem odnosu. Sledove omenjenih izročil in magičnih praks je mogoče prepoznati tudi v slovenski folklori, z zanimivimi paralelami v južnoslovanskem, pa tudi vseslovanskem prostoru.

Za razliko od jezika ptic in divjih živali, so razumevanje govorice domačih živali omogočala semena (pravzaprav spore ali trosi) praproti. Praprotno steblo, ki je bilo povsod v Evropi znano kot čarovniška zel, je po ljudskih predstavah na kresno ali božično noč za trenutek vzcvetelo. Temu namišljenemu cvetu so, tako kot semenom in korenini praproti, pripisovali, da pokaže zakopane zaklade, odpre vsako ključavnico, zdravi bolezni, prežene točo ali pa naredi človeka nevidnega. Njena glavna lastnost pa je, da na kresno ali božično noč imetniku semena omogoča razumevanje pogovorov hlevske živine.

Praprot je bipolarna, podobno kot predstava o svetovnem drevesu. Njen gornji del (cvet in semena) simbolizirata ptica in kvaliteta suhega, medtem ko korenino ponazarjata kača in mokrota. Slovensko izročilo o praproti, dopolnjeno z nekaterimi južnoslovanskimi primeri, vsebuje simbole, ki jih je mogoče povezati v dva niza, izhajajoča iz osnovne binarne opozicije narava - kultura. V prvem nizu si sledijo kača - zemlja - praprotna korenina - voda - mokro - divjina - divje živali - narava, v drugem pa ptica - nebo - praprotno seme - ogenj - suho - dom - domače živali - kultura. Sestavni deli obeh nizov se lahko pojavljajo v vedno novih kombinacijah: tako npr. v eni od pravljic hišni hlapec izve s pomočjo praprotnega semena, da bo gospodarja pičila kača in uspe to preprečiti. V magičnem postopku zaščite hiše pred ognjeno strelo pa so zatikali izruvano praprot v streho tako, da so bile korenine usmerjene proti nebu.

$\mathrm{V}$ tesnem bivanjskem in delovnem sožitju nam je vsakdanja komunikacija z domačimi živalmi razumljiva in logična, bolj zagonetno pa je človekovo sporazumevanje s svetom divjine. Kakšen je bil jezik, ki so ga izbranci domnevno privzeli od kač, ne vemo, posredno pa je mogoče sklepati, da je bil podoben žvižganju. $\mathrm{Na}$ isti način se je po že omenjeni slovenski ljudski pripovedi oglašala bela kača, »mati vseh kač«. Tudi priklicati jo je bilo mogoče z zvoki piščali. Obstajalo pa je še zakoreninjeno prepričanje, da hudič ponoči vodi živali na pašo tako, da jim žvižga.

Hudič v vlogi pastirja je bil krščanski nadomestek za poganskega gospodarja gozda, sivega volka ali šepavega starca, v katerih mnogi strokovnjaki vidijo lik slovanskega htonskega boga Velesa. Po pričevanju slovenskega polihistorja Valvasorja so konec 17. stoletja kmetje v Beli Krajini lovili rake tako, da so jim žvižgali. Na Cerkniškem jezeru so poznali nekoliko drugačno metodo za nabiranje pijavk: recitirali so jim kratke besedne formule v ritmični obliki, kot da bi peli. Požvižgavanje in ritmično petje se je v nekaterih primerih obdržalo do današnjega časa pri poveljevanju volovskim vpregam.

Med druge besedne obrazce spadajo klicanje murnov iz njihovih lukenj, prošnje pikapolonicam naj vzletijo in polžem, naj pokažejo roge. Obstoj kompozicijsko 
in vsebinsko podobnih »pesmic« pri drugih slovanskih narodih kaže, da je to del skupne kulturne dediščine in da so vsaj v nekaterih primerih to prežitki staroslovanskih obrednih besedil.

Dr. Zmago Šmitek, Professor emeritus [University of Ljubljana], 4245 Kropa 77, Slovenia, Zmagosmitek@yahoo.com 